http://dx.doi.org/10.11646/phytotaxa.175.3.5

\title{
Rhynchosia ravii (Leguminosae-Papilionoideae), a new species from Andhra Pradesh, India
}

\author{
K. PRASAD ${ }^{1 *} \&$ A. NARAYANA SWAMY ${ }^{2}$ \\ ${ }^{1}$ Botanical Survey of India, Deccan regional centre, Hyderabad-500048 \\ ${ }^{2}$ Biodiversity Conservation Division, Department of Botany, Sri Krishnadevaraya University, Anantapuram- 515 003, Andhra Pradesh, \\ India. \\ Corresponding e-mail : prasad.orchids@gmail.com
}

\begin{abstract}
Rhynchosia ravii, a new species from Andhra Pradesh, India is described and illustrated. Full description, distribution details and conservation status are presented, and the new species is compared with its most closely related species, Rhynchosia beddomei.
\end{abstract}

Key words: Fabaceae

\section{Introduction}

The genus Rhynchosia Loureiro (1790: 460) comprises about 230 species distributed throughout the tropical regions of the world, the main centre of distribution being Africa to Madagascar (Mabberley 2008). In India the genus is represented by 25 species, as well as one variety and one subspecies (Baker, 1876; Sanjappa, 1991), of which 7 species are endemic to India. In India, a great diversity of the Rhynchosia species, around 60\%, are found in the Eastern Ghats (Gamble 1928, Pullaiah \& Sri Ramamurthy 2000). During a recent floristic exploration in the spurs of the southern Eastern Ghats in Anantapuram district and Mangapatnam area in Kadapa district, we found a population of a species of Rhynchosia in dry deciduous forest with a grassy understorey. Detailed studies of the specimens, and of the literature, comparing the new material with herbarium specimens deposited at BSID, CAL, MH, and SKU, revealed that the newly collected specimens did not belong to any known species of Rhynchosia in India. The material therefore represents a new species, closely related to Rhynchosia beddomei Baker (1876: 222). In vegetative condition, the two species are morphologically similar, but the new species is distinguishable by the presence of glandular hairs. Initially, the present specimens were mistakenly identified as $R$. beddomei because both the species display the dense, short, fine indumentum of greyish white hairs on all the vegetative parts. The two species are distinguished mainly on the basis of their flowering and fruiting characters. $R$. beddomei is probably endemic to Andhra Pradesh (Seshachalam hills of the Eastern Ghats in Chittoor and Kadapa districts) and Karnataka states: Gamble (1928) reported the occurrence of this species from Bellary District, but there are no known collections from this area. The new species is endemic to the Anantapuram and Kadapa districts of Andhra Pradesh state. Here the new species is described and illustrated.

\section{Material and Methods}

The description is based on measurements of living plants taken in the field and of herbarium specimens. Dried herbarium specimens, and specimens collected in FAA (Alcohol 70\% + Acetic acid 5\% + Formaldehyde 5\% + Distilled water $20 \%$ ) solution were studied using a binocular microscope. The conservation status proposed here follows the Red List Categories and Criteria, version 11 (IUCN 2014). 


\section{Acknowledgements}

The authors gratefully acknowledge Department of Biotechnology (BT/PR6603/NDB/51/089/2005), MST, GOI, New Delhi for financial assistance. We are grateful to Dr. M. Sanjappa, UAS, Bangalore for guidance and critical comments. We thank Dr. P. Singh, Director, Botanical Survey of India, Kolkata; Dr. P. Venu, Additional Director and P.V. Prasanna, Joint Director, Deccan Regional Centre, Botanical Survey of India, Hyderabad for their help and encouragement.

\section{References}

Baker, J.B. (1876) Rhynchosia. In: Hooker, J.D. (Ed.) Flora of British India vol. II. L Reeve \& Co., 5, Henrietta Street, Covent Garden, London, pp. 220-226.

Gamble, J.S. (1928) Flora of the Presidency of Madras, Vol. 1. Adlard \& Son, limited, 21, Hart Street, W.O., London, pp. 371-376.

IUCN Standards and Petitions Subcommittee (2014) Guidelines for Using the IUCN Red List Categories and Criteria, Version 11. Prepared by the Standards and Petitions Subcommittee of the IUCN Species Survival Commission. Available from: http://jr.iucnredlist.org/ documents/RedListGuidelines.pdf (accessed February 2014)

Loureiro, J.D. (1790) Flora Cochinchinensis vol. 2, pp 460.

Mabberley, D.J. (2008) Mabberley's Plant-Book. A portable dictionary of plants, their classification and uses. Third Edition. Cambridge University Press, Cambridge.

Pullaiah, T. \& Sri Ramamurthy, K. (2000) Flora of Eastern Ghats, hill ranges of south East India, Vol. 2 (Leguminosae). Regency publications, New Delhi, pp. 300-322.

Sanjappa, M. (1991) Legumes of India. Bishen Singh Mahendra Pal Singh, Dehra Dun, India, pp. 236-241. 